\title{
The Profile of the Romanian Voter in European Elections
}

\author{
Claudia Elena Ionaș
}

Doctoral School in Sociology, National University of Political Studies and Public Administration, Romania

\section{ARTICLE INFO}

Keywords:

Behaviour

Exit Poll

Social Change

Turnout

Voting

\begin{abstract}
A European voter is a person who has their own political, social, and cultural background, while sharing a main goal with other Europeans: preserving democracy and the values and benefits that it entails. With more than 400 million people eligible to vote the result of the European elections has a great impact on European policies and national agendas. The turnout average in 2019 European elections was 50,66\%, but for Romania, although it was close to average, $51.20 \%$, it registered a significant step forward. In 2007 the Romanian people voted for the first time for the European Parliament, but only $29,22 \%$ out of the over 18 million Romanian electors cast their vote. The trend was similar until last year. What has happened in the last decade in Romania that has driven a twofold increase in turnout? Political turmoil has fueled political participation: higher turnout and protests against governmental actions. Focused on European elections, the study of the Romanian voter profile is based on the results of exit polls conducted in 2014 and 2019 in European elections held in Romania, with insight on social and political changes that have shaped the electoral behaviour of Romanians as citizens of the European Union.
\end{abstract}

\section{Introduction}

Political participation has been one of the most studied issues in political sciences in the past decades. Furthermore, rapid transformations of societies and the impact of globalisation have shaped political behaviour. Yet, for former communist countries, the major challenge was to reassess societies. The study of political participation in Romania is in progress, but new realities call for further exploration of the subject. Romania, which joined the European Union in 2007, ranks 6th by population number, with 22.174 .693 million citizens. A former communist country until December 1989, during the last 30 years, Romania has seen a lengthy transition, and changes have had a significant impact on society. The challenges that the new democratic society has faced have first of all greatly influenced social, as well as political behaviours. Referring to post-communist transition, Romanian sociologist Claudiu Tufiş underlines the specificity of transformations that have occurred, defining them as a "dramatic social change" (2012:33). Elections in our young democracy have been significantly different than elections held during the Communist regime. While before 1989,

\footnotetext{
* Corresponding author E-mail address: claudiaionas@gmail.com

Cite this article as:

Ionaș, C. E. (2021). The Profile of the Romanian Voter in European Elections. Journal of Advanced Research in Social Sciences, 4(1), 1-20. https://doi.org/10.33422/jarss.v4i1.687
}

(C) The Author(s). 2021 Open Access. This article is distributed under the terms of the Creative Commons Attribution 4.0 International License, which permits unrestricted use, distribution, and redistribution in any medium, provided that the original author(s) and source are credited. 
the rate turnout was close to $100 \%$, the 1990 general elections saw a turnout that soared past $86 \%$, before plummeting to under $40 \%$ at the 2016 parliamentary elections.

Socio-demographic factors have been long studied in connection with the process of voting (Lazarsfeld et al., 2004; Berelson et al., 1986; Blondel, 1963; Mayer and Schweisguth, 1989). Social group affiliations such as social class, place of residence (urban/rural) and religion are linked with voters' political options (Lazarfeld et al., 2004:197). Due to the fact that Romania is an Orthodox-majority country religion is not taken into consideration in this paper. Orthodox Christians represent $86,5 \%$ of the population of the country and Roman Catholics only 4,6\%, while Protestants and other Christian make up 5,9\%. Only 0,2\% consider themselves atheists (The National Institute of Statistics in Romania, 2013). The relation between occupation and voting is strongly connected (Campbell et al., 1980; Butler and Stokes, 1974; Michelat and Simon, 1971, Mayer and Schweisguth, 1989). Mayer and Schweisguth (1989:265) underline that the correlation between the professional occupation and voting occurs on two levels. The first level refers to the employment-unemployment dichotomy, and the other to the hierarchy within the two categories. Besides, the direction of the vote is related to income and the level of education. Campbell and al. (1960:385) stress that: "One's occupation, the economic base of one's community, the direct or indirect experience with economic crisis - all of these are unmistakable logical or temporal antecedents for one's political and economic interests." In the case of a cross-status, electoral options may differ regardless his status: "Occupation, although a central index of status, can also provide a social medium in which status differences in political attitudes may become blurred" (Campbell et al., 1960:483). Comparing the results and the profile of the Romanian voter in European elections in 2014 and 2019 it is obvious that university students who in the 2014 elections opted for PSD voted for the new party USR (47\%) in 2019. This highlights the fact that new voters (the students' average age ranges between 19 and 24) can change the result of elections (Franklin, 2004:60). Furthermore, this category's habit of voting is important in order to estimate the next elections' turnout. As Eric Plutzer (2002) underlines, inertia has a great impact on turnout in connection with the first vote participation. When comparing the 2014 elections with the 2019 elections, we must primarily take into account the difference in turnout. Thus, in 2019 the turnout stood at 51\%, while in 2014 it dropped to $32 \%$. Education is a factor that may affect electoral behaviour. Norris (2004:19) considers that extending mass education and access to information have enabled a "shift from the politics of loyalties toward the politics of choice". Butler and Stokes (1974:102) underline that it "preserves the occupational status quo", which is linked to a lesser extent to political conversion than the social and political background of the person. The electoral behavior of voters often changes between elections. This is why the electoral volatility has long been studied (Berelson et al., 1986; Butler and Stokes, 1974). Berelson et al. conclude that the unstable voters are influenced by the cross-pressured opinions. Furthermore, they underline that: "Stability in vote is characteristic of those interested in politics and instability of those not particularly interested" (Berelson et al., 1986:20). The way that social groups encompassing voters influence the result of European elections in Romania is analysed in the sociodemographic profile.

For Romania, due to the political and social context before the fall of the Communist regime, social changes occurred in waves. The population needed to adapt rapidly to new realities: a new labour market, privatization of enterprises, and the responsibility of finding a workplace, which in Communism was a given fact. The new democracy came with rights and liberties that Romanians have integrated gradually - freedom of speech, as well as the right to travel and to work abroad. Freedom to vote, obtained in 1990, was by far the most important right: being able to decide the political trajectory of the country. While voting in elections in Romania has decreased in the last 30 years, political participation has evolved. In the past 
decade, protesting has become a new tool to influence social change and governing policies. New small parties have entered Parliament and managed to climb up the echelons of political power.

Between 1990 and 2020, Romania has had four presidents and seen four changes of power. Ion Iliescu was the first President of democratic Romania after the fall of the communist regime. He was elected in 1990, 1992 and 2000, respectively, but in 1996, he lost the elections to Emil Constantinescu, the only Romanian President who no longer ran after a four-year term. In 2004, Traian Băsescu became President. Five years later he managed to secure another term in office. He was the first Romanian President to lead the country for ten consecutive years. In 2014, incumbent President Klaus Iohannis won the elections and in November 2019, he was re-elected for a second term.

\subsection{The Political Background of the European Elections in Romania}

Romania has a semi-presidential republic system. Its Parliament has two chambers: The Chamber of Deputies and the Senate. Lawmakers are elected by direct popular vote for a four-year mandate.

The history of European elections in Romania is recent, with new political realities shaping the future of civic engagement. 55\% of Romanians appreciate the country's EU membership (Mihai, 2019). Franklin (2017:2) considers European elections "second rate" because of "the lack of policy consequences." From his point of view, as compared to national elections, EP elections don't have the same impact because the most important elections are the ones conducting to government formation. This is why he stresses that it is difficult to urge people to vote, except for small parties for whom they represent "targets of opportunity."

To understand the way Romanians voted in European elections and to outline their profile, a review of the political facts that have opened in our country's recent history is necessary. Until a Constitutional revision in 2004, parliamentary and presidential elections took place at the same time. As of 2008, they are scheduled separately. Looking back at the recent history of elections in Romania, some patterns can be noticed: elections held between another two types of elections represent a direct evaluation of officials in power and act as a way to sanction or support politicians. In 2008, the presidential party (Democratic Party - PD) won the elections and continued to govern until 2011. In 2009, President Traian Basescu won by a narrow margin the elections that pitched him against Mircea Geoană (the now deputy Secretary-General of NATO). The effects of the financial and economic crisis in Romania already had already taken their toll on the population. Despite having announced unpopular austerity measures, President Traian Băsescu managed to secure another term in office.

Romania joined the European Union on 1 January 2007 and the first European elections there took place in November 2007. Simultaneously, Romanians voted in a referendum over changing the electoral system into uninominal voting. Nowadays, Romania has a closed party-list proportional system. The country is not a member of the Euro area, nor is it a Schengen zone member. In May 2007, the President of Romania was impeached and survived the referendum. He was the first and only president of the country to be officially impeached, but during his last term in 2012, he was impeached for a second time by Parliament. While in 2007, before the European elections, Traian Băsescu was very popular among Romanians, in 2012, the acute political polarisation reached a peak. The last two years of his term were difficult, and with a ruling majority against him, he managed to find a way to cohabitate with leftist Prime Minister Victor Ponta, who was backed by the Social Liberal Union (USL) - an alliance of socialists and liberals between the Social Democratic Party (PSD) and the National Liberal Party (PNL). Positioned on the centre-left of the political spectrum, PSD is the largest social-democrat party in Romania (The Social Democratic Party, 
n.d.). PNL is a conservative-liberal political party and the second largest party in Romania. PNL is considered a centre-right party (National Liberal Party, n.d.).

In 2009, European elections took place in June and presidential ones in November, along with a referendum over the reduction of the number of MPs to 300 and the conversion of the bicameral Parliament into a unicameral one. The winning party in the European election was the Social Democratic Party which struck a political alliance with a small party, the Conservative Party, thus forming the PSD+PC Alliance. Comparing the slim difference between the first and second positions in the resulting hierarchy, the PSD+PC Alliance managed to obtain 1,36\% more votes than the ruling Democratic Liberal Party which ranked second. A small difference, but six months later, in the elections that pitched him against Mircea Geoană (the leader of PSD), President Traian Băsescu, backed by the PDL, reversed the result and won the elections with a mere $0,68 \%$. This was smallest difference in the history of presidential elections in Romania. The elections may act as a performance evaluation of the politicians, mainly for those in power.

From a political point of view, 2012 was a challenging year, as problems emerged in the wake of an extended and costly economic crisis. Political realities topped the public agenda. The first protests were held early into the new year, after the government announced a new healthcare bill. It was only the beginning of street protests. The Government led by Emil Boc withdrew the bill but eventually resigned ${ }^{1}$. Social movements fill an important place in the research of political participation in Romania in the past decade. After almost three years of deprivations, a spark was need for the population to voice its dissatisfaction. In July 2012 President Traian Băsescu was once again impeached by the USL Alliance. The former President managed to reclaim office after calling on people to boycott the referendum. The turnout was $46 \%$, and the Constitutional Court ruled the referendum void. The new alliance USL won the 2012 parliamentary elections with a historic score: $66 \%$ of the votes cast.

In 2014, two rounds of elections took place: European and presidential elections. National Liberal Party candidate Klaus Iohannis won the latter with 54,43\% of the votes (Central Election Bureau of Romania, 2014). An ethnic German and former leader of the Democratic Forum of Ethnic Germans in Romania, Iohannis had joined the party in 2013 and had been elected as its leader just months before the presidential elections (Presidential Administration of Romania, n.d.).

The socialist party PSD won the 2016 parliamentary elections (with 45,5\% of the votes) with a social governing program, and formed a cabinet with Sorin Grindeanu as Prime Minister. At the beginning of 2017, President Klaus Iohannis denounced the intention of the then ruling party to issue an emergency ordinance on the laws of the judiciary (The Government of Romania, 2017) that could have undermined the fight against corruption (The Presidential Administration of Romania, 2017). Romanians gathered to protest in Victoriei Square, in front of the Government headquarters. This marked the start of the greatest protests in Romania after the fall of Communism. The Government caved in under street pressure and repealed the decree, but rallies raged on. Prime Minister Sorin Grindeanu was ousted, in a noconfidence vote submitted by his own party. The protests turned into a large-scale social movement under the name \#Rezist and were regularly held until 2019, but the number of participants gradually decreased. The messages of riots in Romania promoted European values and consolidated a shared EU spirit.

European elections were held on May $26^{\text {th }} 2019$, just six months before the Presidential elections in Romania, so they were seen as a milestone for all parties. Throughout 2019, the

${ }^{1}$ Nine years after the failed attempt to reform the healthcare system, Romania has an ailing medical system. With the heavy toll taken by the COVID-19 pandemic, Romania currently faces a great challenge to overcome the situation. 
main focus of local parties was the electoral agenda. The European elections were the third round of elections in Romania for a full mandate in the European Parliament and the fourth since Romania joined the European Union on January $1^{\text {st }} 2007$. Turnout had been low in these elections, in the past, mainly because European issues were not viewed as bearing direct influence on Romanians' daily lives. When the 2019 European Elections were held, the country was ruled both by President Klaus Iohannis and the majority Social Democratic Party (PSD) - Alliance of Liberals and Democrats (ALDE). President Iohannis, in the midst of his own campaign to get re-elected, was backed by the PNL.

In Romania, the result of the latest EP elections of May 2019 revealed that small parties obtained a great victory. The newly formed Save Romania Union, registered in 2016, managed to secure $22,36 \%$ of the votes, which placed it 3 rd among voters 'preferences. How could a new party lacking the infrastructure of ancient parties achieve such a victory? The new political configuration of Romanian parties in the EP could sway the internal political life. Although within this interval two rounds of elections took place - presidential elections in November of last year and local elections in September of this year, it was difficult for a new party to win the presidency of the country or obtain a comfortable majority in local elections, without the institutional structure of an old party. Parliamentary elections in Romania were held in December. The great success attained by the USR Party in the 2019 European elections was not reached in the 2020 elections, but the USR managed to come in 3rd in voters' preferences. The elections brought to the fore the unexpected emergence of an extremist party in Parliament the Alliance for Romanian Unity (AUR). The 9\% score of AUR (Romanian for gold) baffled society as the party had been nowehere on the public agenda prior to the parliamentary elections. Nor did it run a campaign in the mainstream media. It was founded in November 2019 by George Simion, who run, as an independent, in the European elections of 2019 and won 117.141 votes (Central Election Bureau of Romania, 2019).

The Social Democratic Party obtained a score that offered the party the possibility to lead the country and form the government. Six months after winning the elections, PSD withdrew the support for social democrat Prime Minister Sorin Grindeanu. It was the first no-confidence vote of a party against its own Prime Minister. Mihai Tudose replaced Sorin Grindeanu, but six months later he resigned as his party withdrew its backing. In January 2018 European Parliament lawmaker Viorica Dăncilă became the first female Prime Minister of Romania. After two years and three Prime Ministers, the alliance PSD-ALDE collapsed after a noconfidence vote and Ludovic Orban, opposition leader and head of the National Liberal Party, became the new Prime Minister.

Even though the National Liberal Party formed the new government, the centre-left party had the majority in Parliament until December 2020. The speaker of the Chamber of Deputies was Marcel Ciolacu, after former PSD leader Liviu Dragnea was jailed for corruption. After the 2016 legislative elections, PNL won 68 seats in the Chamber of Deputies (The Chamber of Deputies, n.d.) and 25 in the Senate (The Senate of Romania, n.d.), out of 465 MPs. Without the support of Parliament, the government running the country lacked power to pass laws. The elections of December $6^{\text {th }}$, which took place against the backdrop of a Covid sanitary crisis, played a significant role for the liberal party which managed the crisis throughout the year. Both the President and the Prime Minister were backed by PNL. The head of state publicly endorsed the activity of the Orban Cabinet and parliamentary elections have been a test for the incumbent President one year after re-election in office and for the governing party. The socialist party PSD won the first place but didn't manage to gather a majority to govern. The results determined the resignation of Prime Minister Ludovic Orban. PNL had to form a ruling majority with the new USR-Plus Alliance and with the Democratic Alliance of Hungarians in Romania (UDMR). 
From an economic point of view, as compared to other UE members, Romania has not managed to overcome shortcoming during the last three decades. It fills one of the lowest positions in the EU27 as regards income, standard of living and at-risk-of-poverty rate. It has the largest at-risk-of-poverty-rate, with almost a quarter of the population at risk of poverty: $23.5 \%$ (Eurostat, 2020).

Regarding the economic disparities between countries, Acemoglu and Robinson (2012:73) assess that: "Countries differ in their economic success because of their different institutions, the rules influencing how the economy works, and the incentives that motivate people." While other approaches underline that the link between economic aspects and the political behaviour is connected with the political context (Franklin et all, 2007). The Romanian elections are an example of how political circumstances were more important than economic growth. In 2014, Prime minister Victor Ponta lost the presidential elections; in 2019, PSD lost the European elections. The reverse was recorded in the 2009 presidential elections, when President Traian Băsescu was reelected in the midst of an economic crisis.

\subsection{The Profile of the Romanian Voter in European Elections}

The rate of participation at the European elections in Romania has been on a trending path since 2007. In 2019, the presence at the polls almost attained the European average. After 3 rounds of elections when the interest of the Romanian voters was low and the presence slightly passed by $30 \%$, the European elections held in 2019 came as a surprise for the political parties: $51,20 \%$ of the Romanians voted.

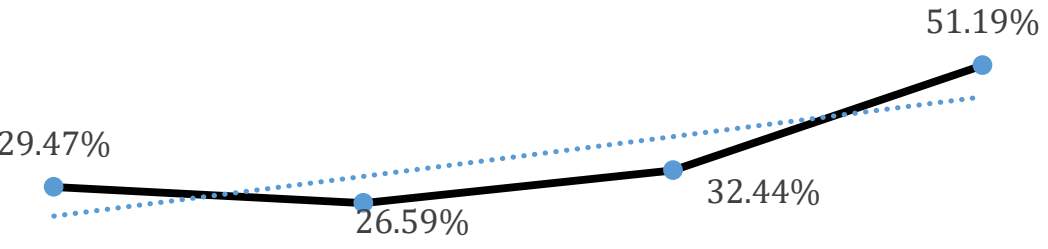

2007

2009

2014

2019

Figure 1. Rate turnout at the European elections held in Romania 2007-2019

Source. Self-made

During the past 12 years, Romania has seen rapid economic and social transformations. Despite the world economic and financial crisis, it has managed to keep effects in check due to hard measures, but its development has slowed down. After the country became a EU member state and began to fully enjoy the opening of EU labour markets, social changes have had a major impact on the lives of many families. The economic benefits they reap are obvious, with Romanians working abroad sending large amounts of money to their families back home. The dire social effects, however, cannot be overlooked, as numerous children are left home in the care of their grandparents or other relatives. Furthermore, elderly members of such families are deprived of proper assistance and support. At the beginning of 2019, Romania held the rotational presidency of the Council of the European Union. So, the European elections in Romania took place during the country's presidency. 


\section{Methods}

In order to be able to identify as accurately as possible the demographic profile of voters of each party, as well as the dynamic of electoral behavior when it comes to elections for the European Parliament, I have analyzed the databases of exit-polls drawn up by the CURS (Center for Urban and Regional Sociology - CURS) and the Avangarde Socio-Behavioral Studies Group institutes for the 2014 and 2019 elections. Although the purpose of this paper is to identify voters' profile with regard to the two sets of elections - 2014 and 2019-, the analysis focuses on the evolution of the parties' results in all 4 rounds of elections for the European Parliament (2007 - partial and 2009). This aims as determining whether throughout these years, given the social, political and economical context, any important changes swayed Romanians' electoral behaviour.

In the case of the 2014 exit poll, more than 15,400 voters were polled. The official election results showed that the estimates were correct both in revealing the winner of the election and the hierarchy of the parties. All estimated percentages in the exit poll had a $1.5 \%$ margin of error.

During the 2019 exit poll, over 22,500 people were polled, in over 400 polling stations at national level. The sample was stratified, on urban and rural areas and on historical regions. In 2019 also all estimates were confirmed by the official election result.

In both cases, it is important to underline that the samples did not include polling stations in EU countries home to large Romanian communities. Over the past years, these groups have been strongly committed to participating in Romania's/have had a major say in Romania's electoral process.

\section{Results}

\subsection{Evolutions of Parties in European Elections}

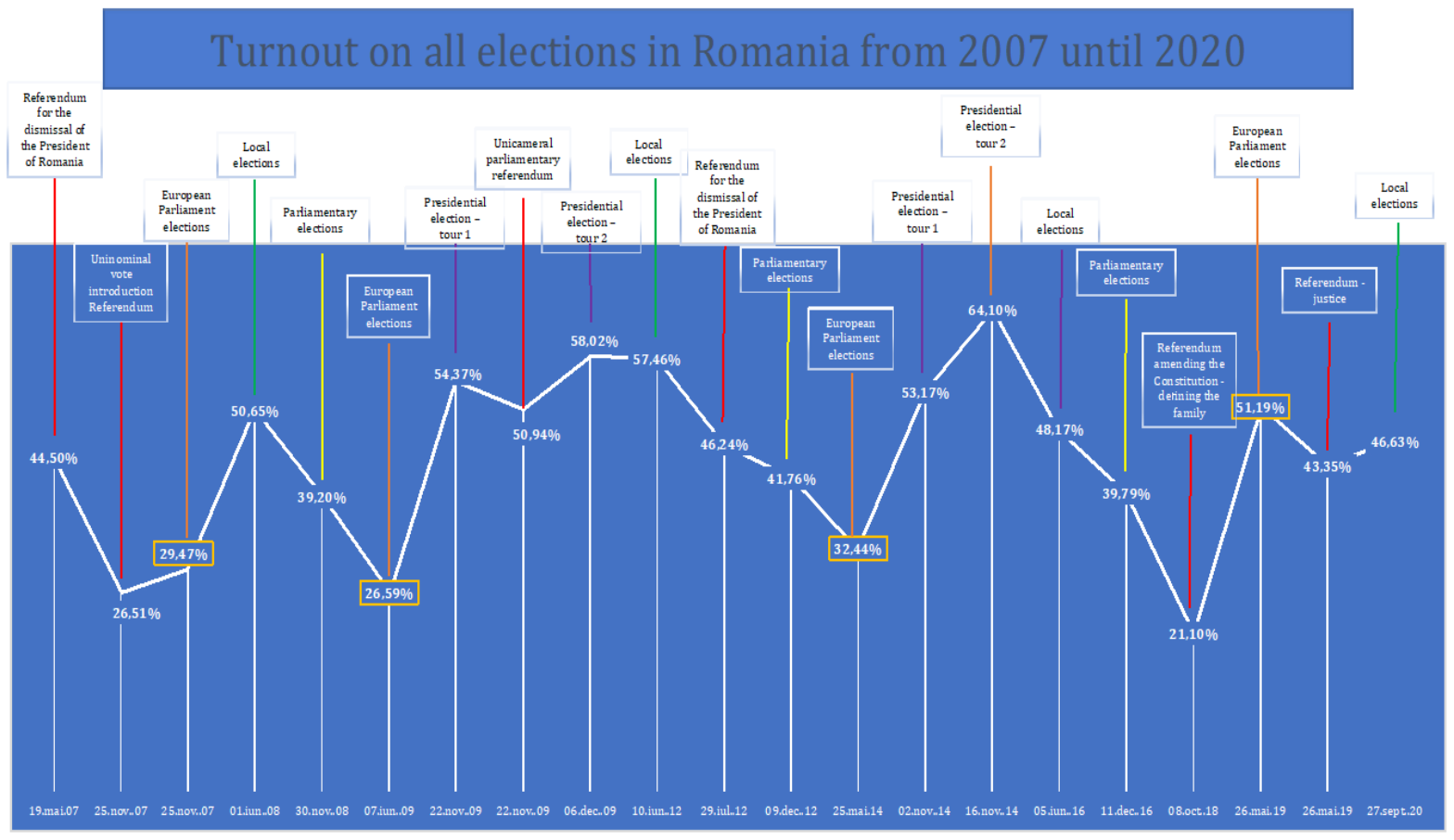

Figure 2. Turnout of all types of elections held in Romania between 2007 and 2020

Source. Self-made 
In the wake of the fall of Communism in Romania, turnout was high. It has seen a constant decline in the past decade. Presidential elections have recorded the highest voter turnout, with a peak at the 2014 Presidential elections when $64,10 \%$ of the eligible population cast their ballot.

The lowest turnout was recorded in European elections in 2009, with 26,59\%. Turnout in parliamentary elections stood at around $40 \%$, but in 2019 , it reached the lowest rate: $31,84 \%$.

Turnout in referenda has always been under 50\%, reaching a low $(21,10 \%)$ in the 2018 family referendum.

The history of the European elections held in Romania (Figure 3) indicates that, except for the 2019 election, PSD won all three rounds of polls.

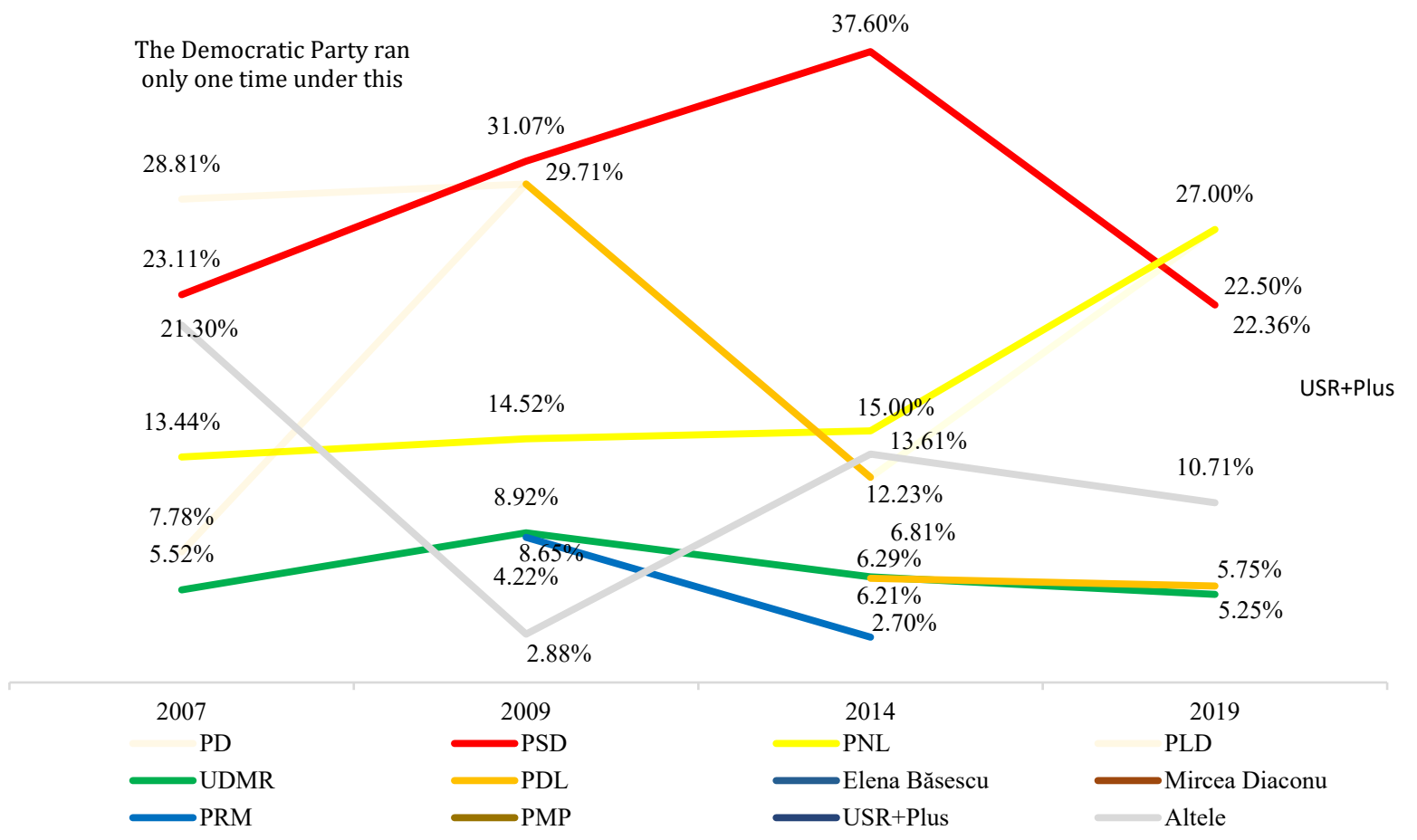

Figure 3. European election results in Romania 2007 - 2019

Source: Self-made

\subsection{Elections for the European Parliament (EP) in Romania - 2014}

Romania had 32 seats in the EP. Turnout at the European elections in 2014 was 32,44\%. PSD, a member of the Party of European Socialists, won the elections with $37,60 \%$ of the votes (16 seats). PNL and Democratic Liberal Party (PDL) participated separately with the former winning 6 seats and the latter 5, but during the same year the two parties merged under the name National Liberal Party (PNL). PNL became a member of the European People's Party (EPP). The Hungarian Democratic Union of Romania (UDMR), also a member of the EPP, was the only small political organisation to have entered the European Parliament since 2007. It won 2 seats. The new party of former President Traian Băsescu (in office at the European elections time) People's Movement Party reached the electoral threshold to get into the European Parliament $(6,21 \%$ - 2 seats). PMP is a member of the European People's Party. 


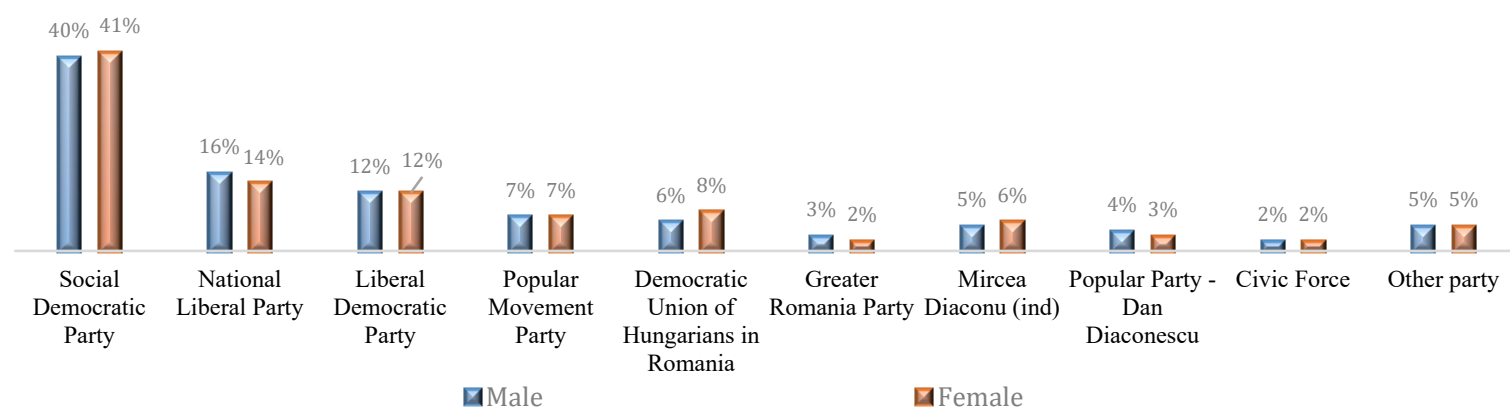

Figure 4. Vote by gender in the European elections held in Romania in 2014

Source. Self-made

Figure 4 indicates that there are no important differences between the electoral behaviour of women and men. Only in the PNL case can we identify $2 \%$ more men than women and in the UDMR case more women than men.

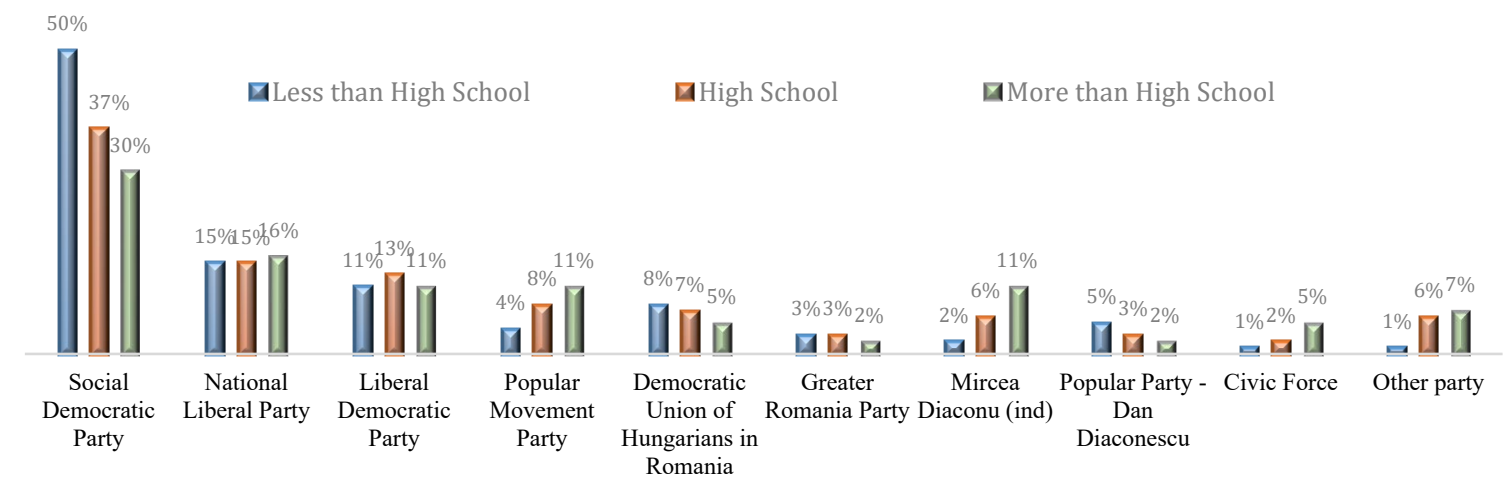

Figure 5. Vote by education in the European elections held in Romania in 2014

Source. Self-made

In 2014, the Social Democrat Party was voted by half of the population with no high school education. $37 \%$ of people holding a high school diploma also voted for this party. The data show that this factor made a real difference on the good result obtained by PSD. The PSD also managed to score $30 \%$ among university graduates, despite poor records regarding preference of the party among this social group.

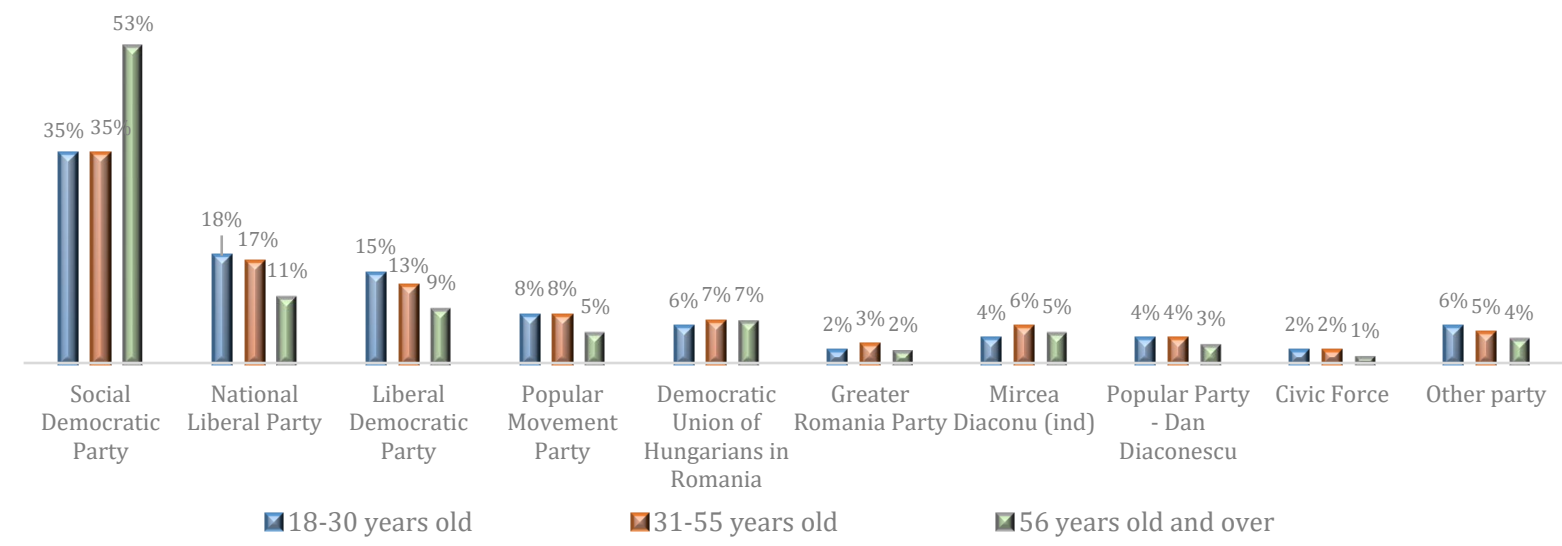

Figure 6. Vote by age in the European elections held in Romania in 2014

Source. Self-made 
As usual, the PSD managed to obtain about half of votes $(53 \%)$ from the 56+ group. An unexpected $35 \%$ was provided by the $31-55$ age group, while an equally surprising $35 \%$ of the 18-30 age group was registered as voting for this party.

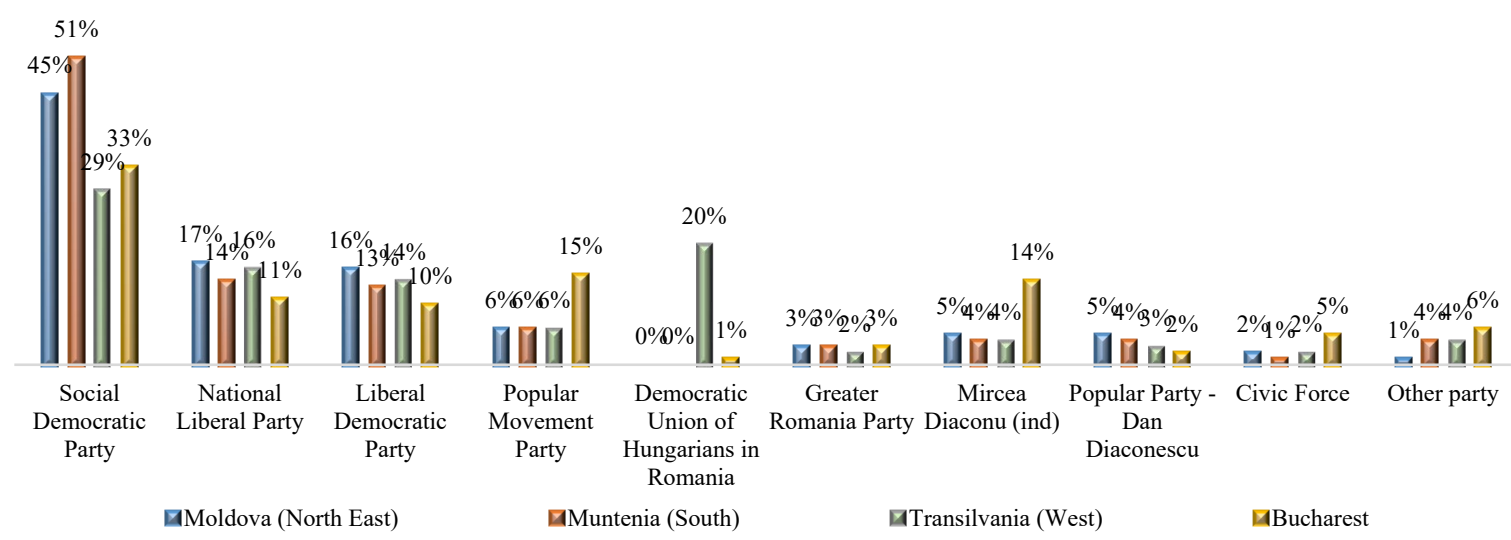

Figure 7. Vote by region in the European elections held in Romania in 2014

Source. Self-made

The PSD has traditionally won elections in Moldavia and Wallachia and lost them in Transylvania and the capital Bucharest. But in the 2014 European elections the Social Democratic Party won by a very large margin in Moldavia and Wallachia. They also managed to win the election in Transylvania where they usually lag far behind the other parties. The UDMR came in close, as Transylvania is home to the biggest ethnic Hungarian community.

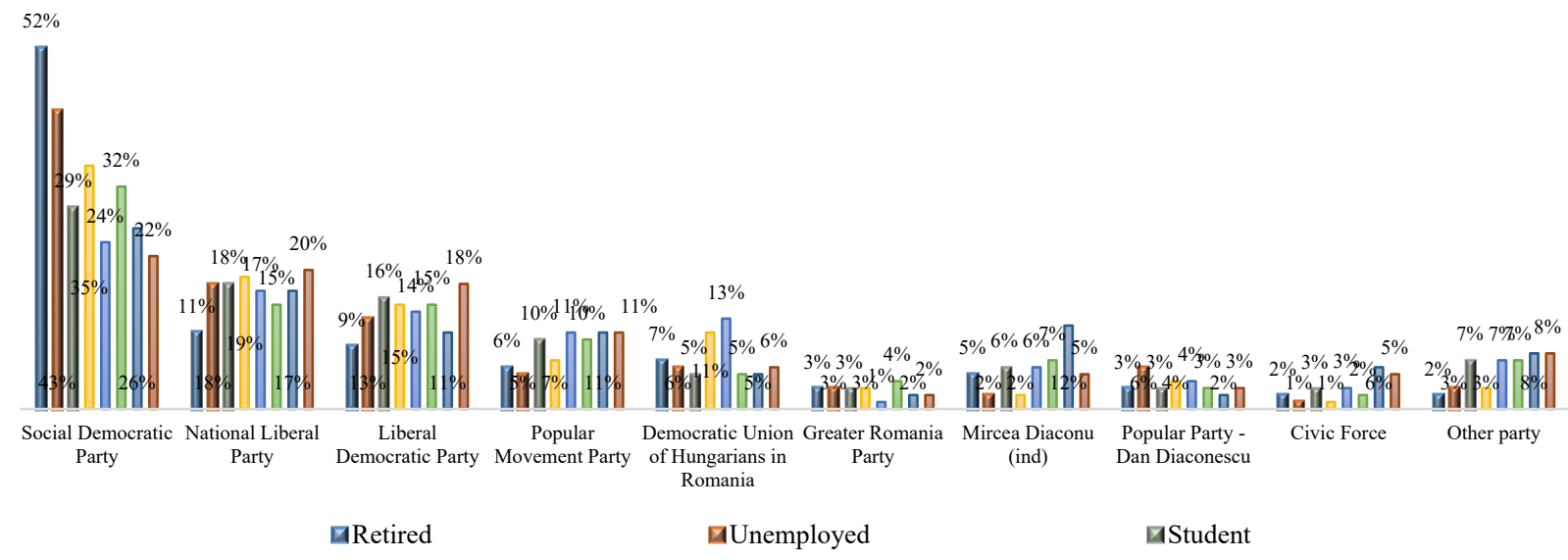

Figure 8. Vote by professional groups in the European elections held in Romania in 2014

Even when we look at how different occupation categories have voted it is unexpected that over $30 \%$ of students voted for PSD.

\subsection{Elections for the European Parliament in Romania - 2019}

Romania had 33 seats in EP. Turnout average in 2019 European elections was 51,20\%, the highest in European elections held in Romania. PNL won the elections with $27 \%$ of the votes (10 seats). It managed to maintain voter's engagement and obtain votes from both political parties, as Figure 3 indicates (PNL 15\%, PDL 12,23\%). The Social Democratic Party 
achieved its worst result in European elections with only 22,5\% of the vote (incurred a 15\% loss). PSD won 9 seats. An increase in turnout had a direct influence on PSD's poor results. The USR-Plus Alliance benefited from the twofold increase in turnout and became the third party in Romania (8 seats). The People's Movement Party (PMP) managed to obtain 5.7\% and former President Traian Băsescu enterd the EP as one of the two PMP members winning a mandate. The Democratic Alliance of Hungarians in Romania won 2 seats.

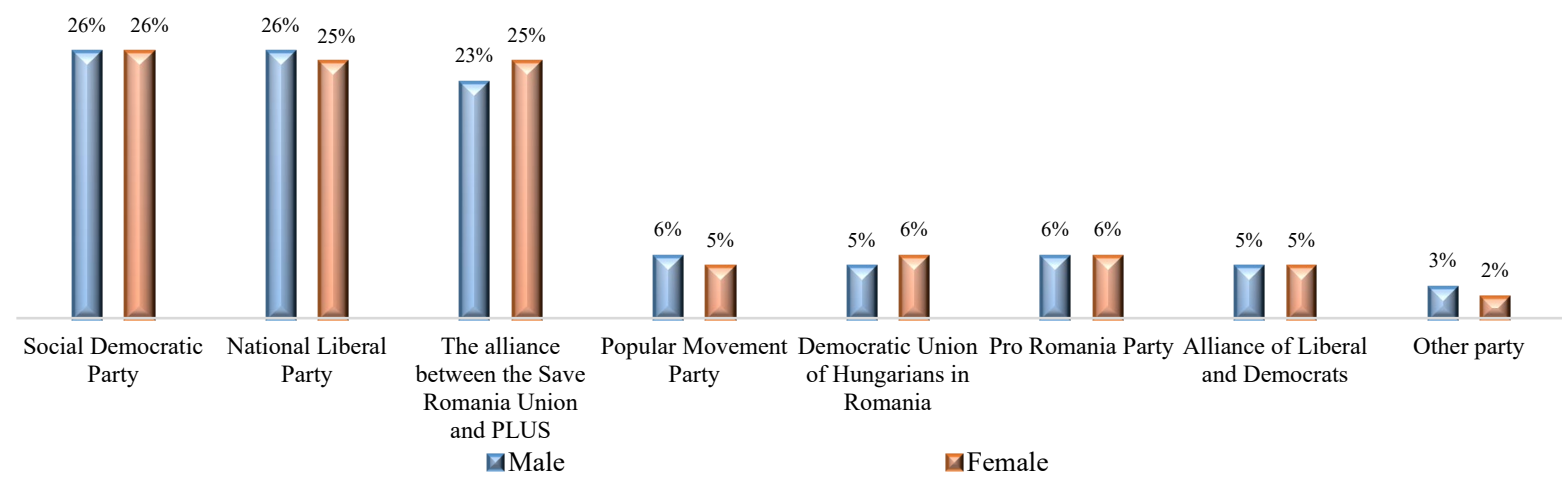

Figure 9. Vote by gender in the European elections held in Romania in 2019

Source. Self-made

Regarding the vote by gender groups, there is no significant difference in the percentage of women and that of men voting in the 2019 European elections.

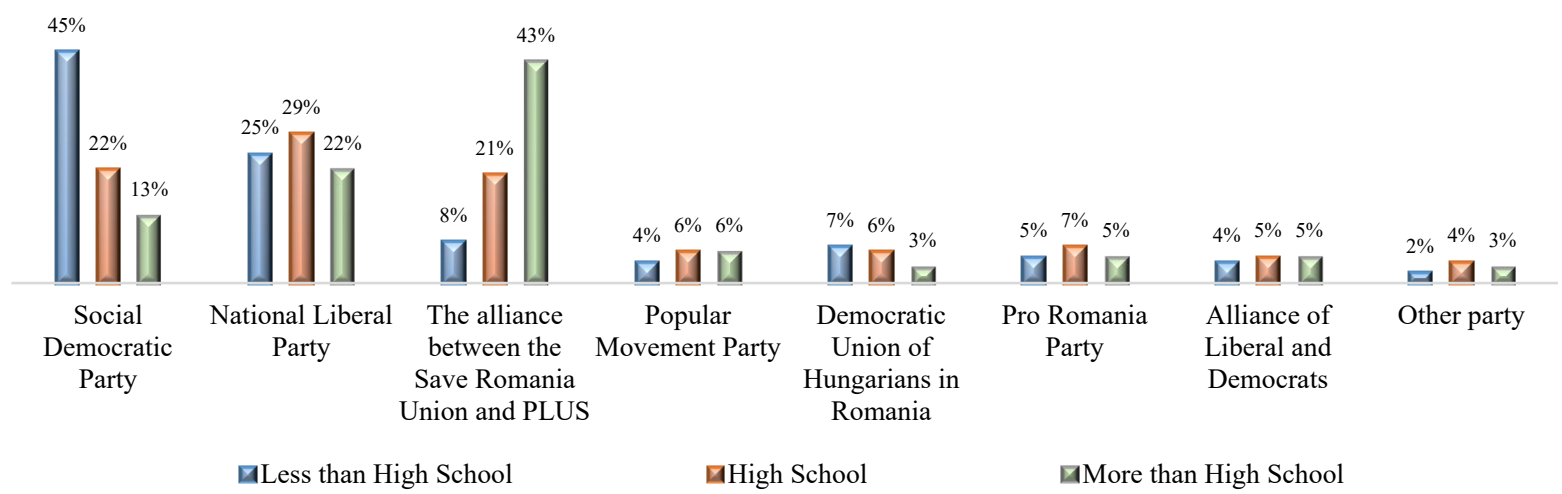

Figure 10. Vote by education in the European elections held in Romania in 2019

Source. Self-made

$45 \%$ of voters with no high school education voted for PSD, a 5\% drop from 2014. The major difference was registered between voters holding a high school diploma - a mere $22 \%$ voted for the Social Democratic Party in 2019, while 29\% voted for PNL. Furthermore, only 13\% of university graduates voted for PSD. In the 2019 European elections, the Save Romania UnionPLUS Alliance managed to obtain $43 \%$ from this category. This was a remarkable score. 


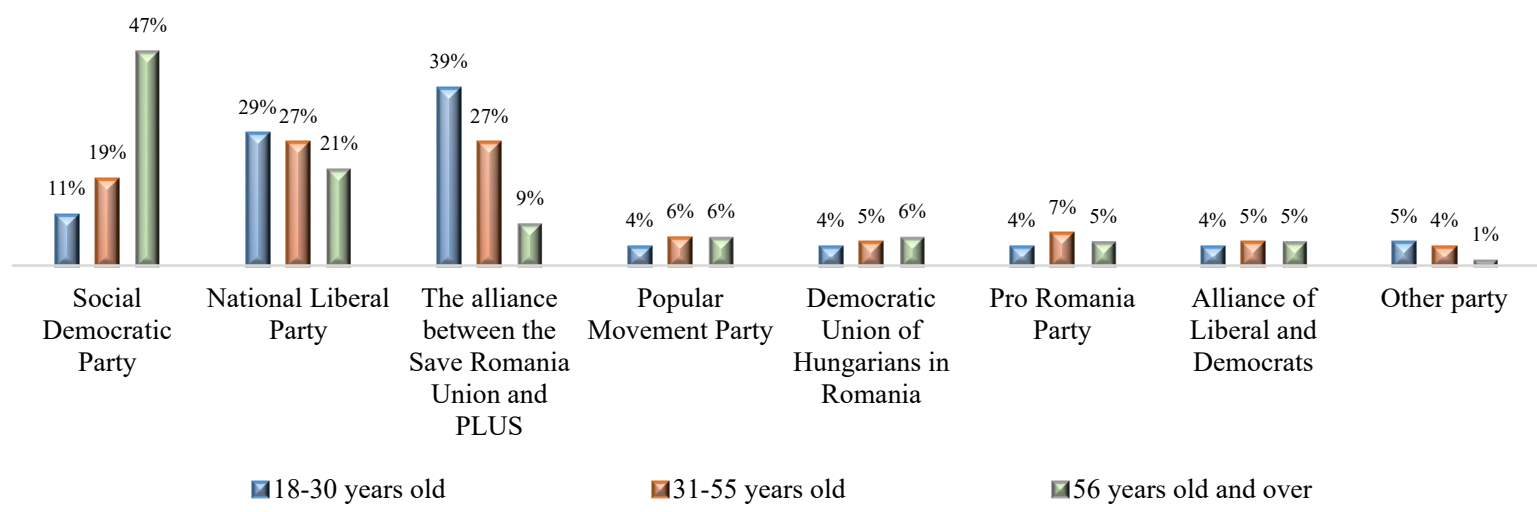

Figure 11. Vote by age in the European elections held in Romania in 2019

Source. Self-made

The data suggest that PSD won the senior vote and USR the younger voters. With regard to the distribution of votes from different age groups, $47 \%$ of people aged 56 or more voted for PSD, while a meagre $11 \%$ was registered within the 18-30 age group. Among voters ages 18 to $30,39 \%$ backed the Save Romania Union-PLUS Alliance, while $29 \%$ voted for PNL. Slim differences in voter preferences by age were registred among voters aged 31-55.

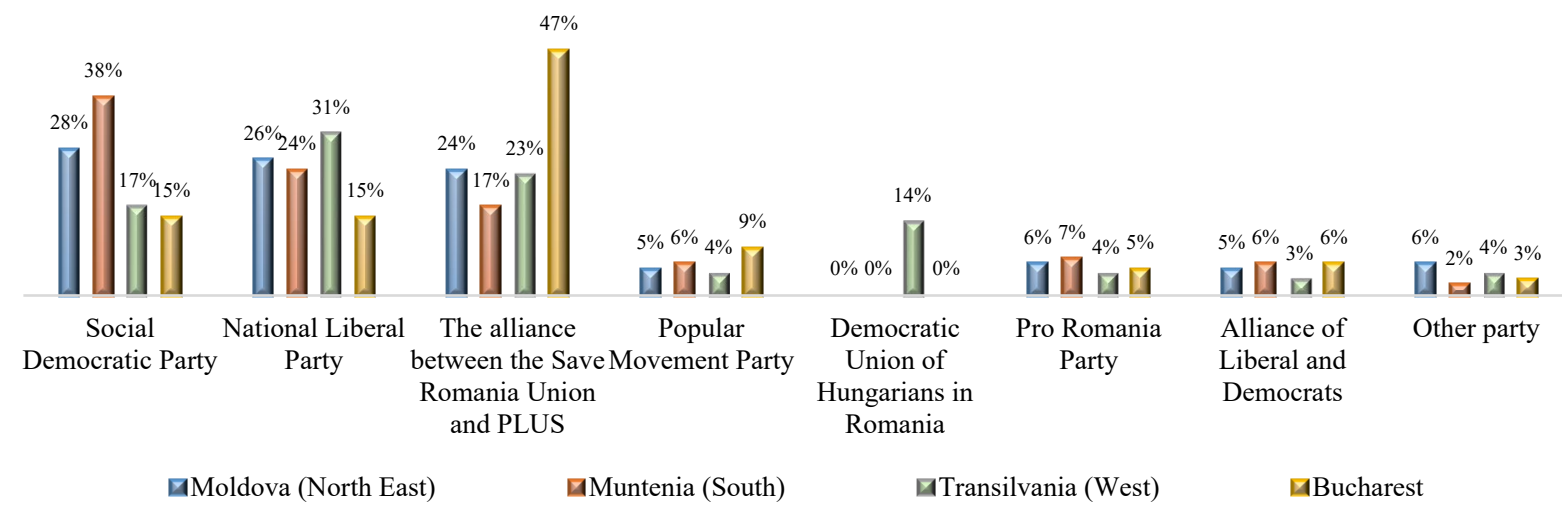

Figure 12. Vote by region in the European elections held in Romania in 2019

Source. Self-made

In the 2019 European elections PSD won Moldavia and Wallachia, with smaller differences than 2014. Transylvania cast more ballots for the Liberals and the USR-PLUS Alliance. In the capital Bucharest the Alliance won by a large margin.

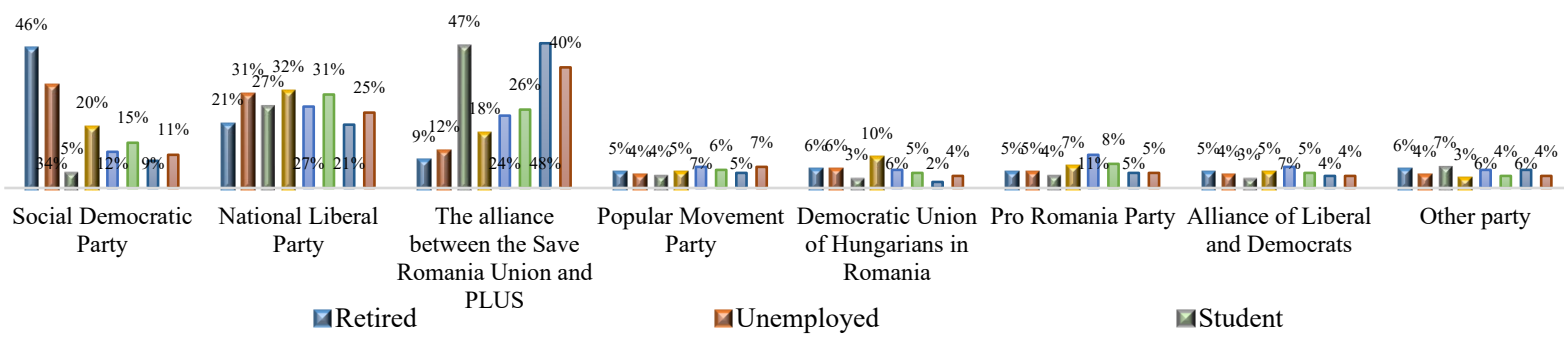

Figure 13. Vote by professional groups in the European elections held in Romania in 2019 Source: Self-made 
With respect to the occupational category, voting patterns in 2019 bore similarities with the 2014 elections, except for student votes. PSD preserved a wide margin among retired voters and unemployed people. $48 \%$ of working university graduates, $40 \%$ of entrepreneurs, $26 \%$ of working high school graduates and a mere $8 \%$ of workers cast their vote for the USR-Plus Alliance.

\subsection{Comparison Between the 2014 Vote and the 2019 Vote in European Elections}

The 2019 European elections held in Romania set a participation record for this type of elections. The turnout reached the European average.

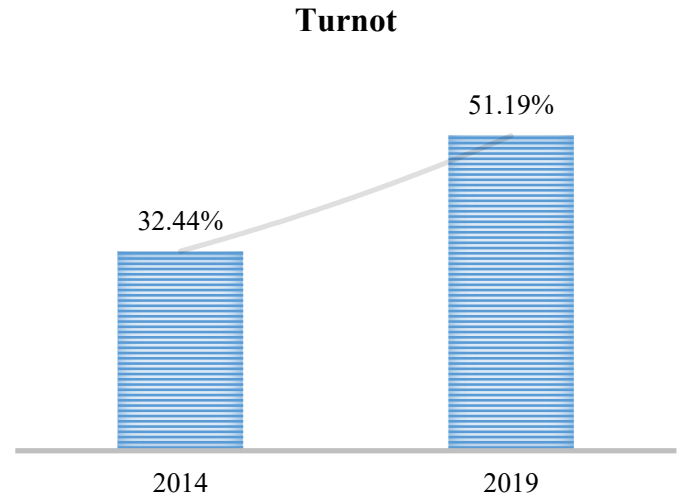

Figure 14. Turnout comparison in European elections in Romania 2014 vs. 2019

Source. Self-made

Comparing the two rounds of European elections in Romania it is obvious that education and professional occupation influenced the decision regarding the vote. Disparities between people with higher and low education levels can be noticed at both rounds of elections.

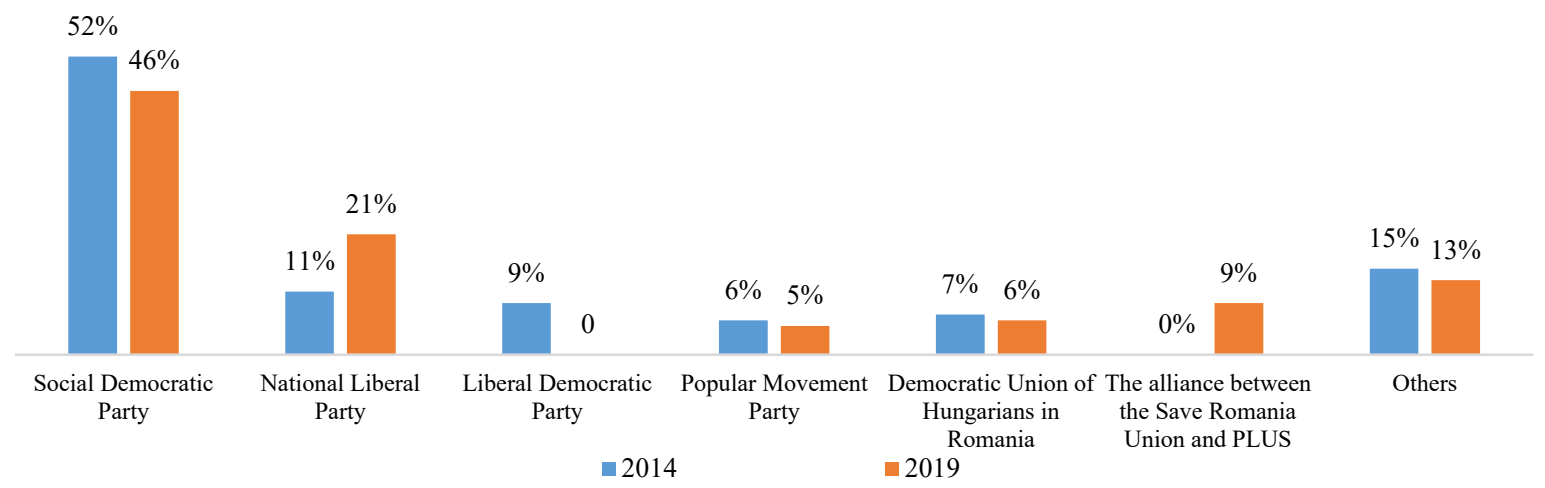

Figure 15. Retirees voting distribution in the 2014 and 2019 European elections held in Romania Source. Self-made

While in the case of retired people and the unemployed no major changes in behavior were reported, with minor differences being the result of increased turnout, with regard to students, $24 \%$ of them decided not to vote for PSD as they did in 2014. 


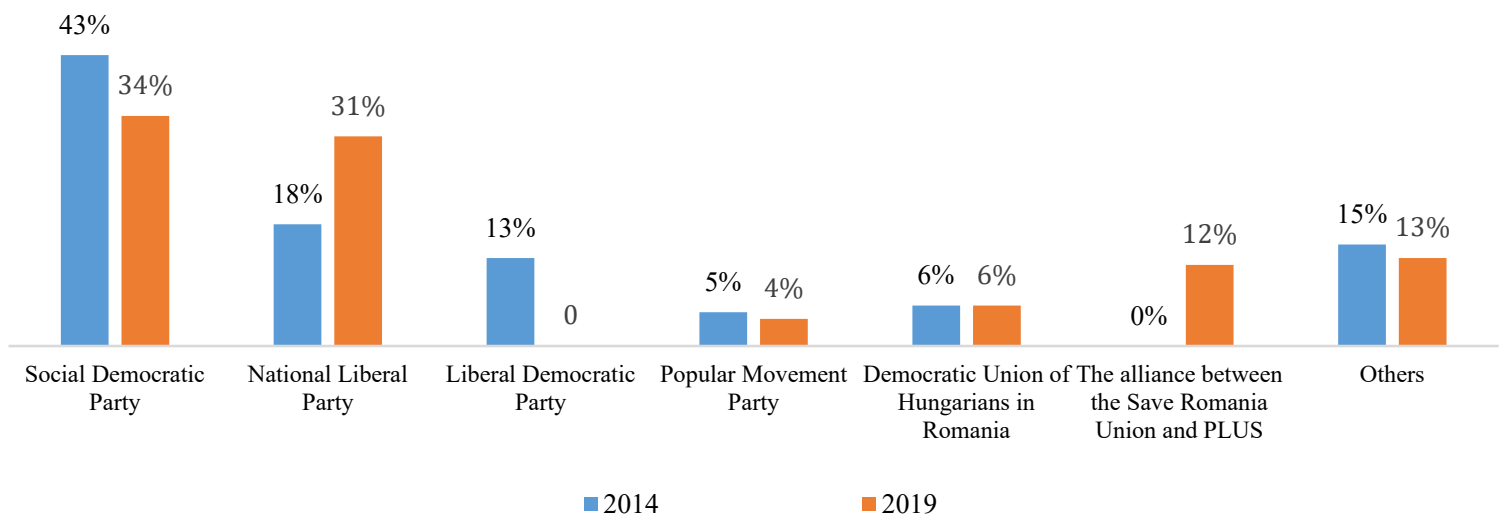

Figure 16. Unemployed voting distribution in the 2014 and 2019 European elections held in Romania Source. Self-made

If we analyse how differently socio-professional categories voted in the two elections, we can see that students and employed voters (those with secondary education and higher education) determined the vote result.

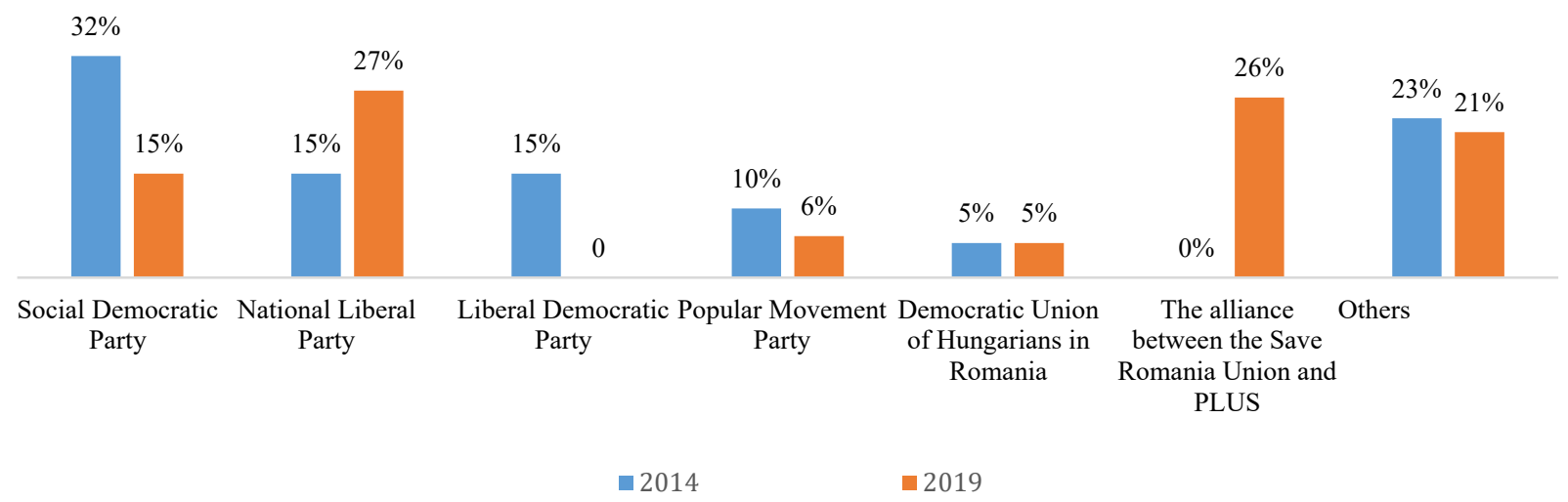

Figure 17. High school employees voting distribution in the 2014 and 2019 European elections held in Romania

Source. Self-made

In 2019, all parties that had run five years earlier were deprived of a share of students' votes, with $47 \%$ of the latter casting their ballot for the newly emerged USR-PLUS Alliance. 17\% of working high school graduates that had previously voted for PSD shifted to USR. The USR-Plus additionally obtained the votes of people who did not turn out in 2014. As compared to results in 2014, PNL won a twofold percentage of votes obtained from working high school graduates. The pattern was similar for working university graduates. 


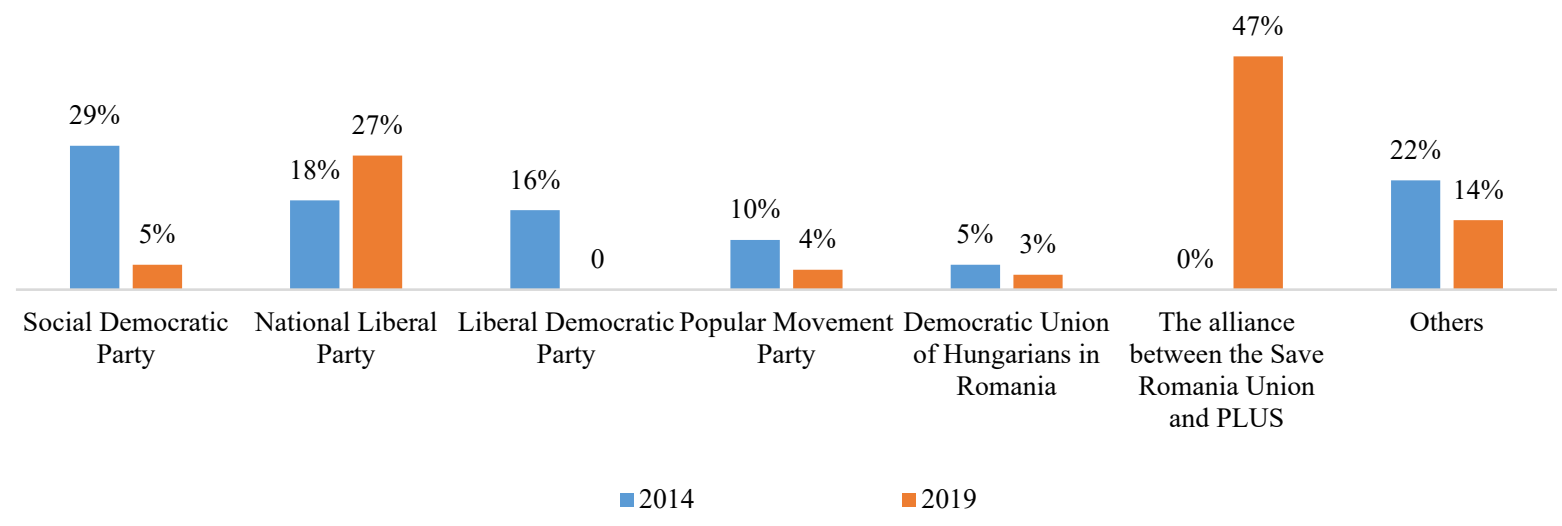

Figure 18. Students voting distribution in the 2014 and 2019 European elections held in Romania Source. Self-made

The large difference between the score of the PSD in 2014 and 2019, respectively, was mainly determined by the options of students in both elections. While in 2014, $29 \%$ of them cast their ballot for the PSD, in 2019 only 5\% still voted for the PSD. In 2019, the new political alliance formed by the Save Romania Union and PLUS managed to win $47 \%$. In 2019 , the new political alliance formed by the Save Romania Union-PLUS managed to win $47 \%$. PNL has obtained more votes from the young persons in the 2019 elections, with $9 \%$ more students voting for the Liberal Party. PNL has gained $27 \%$ of this group's votes.

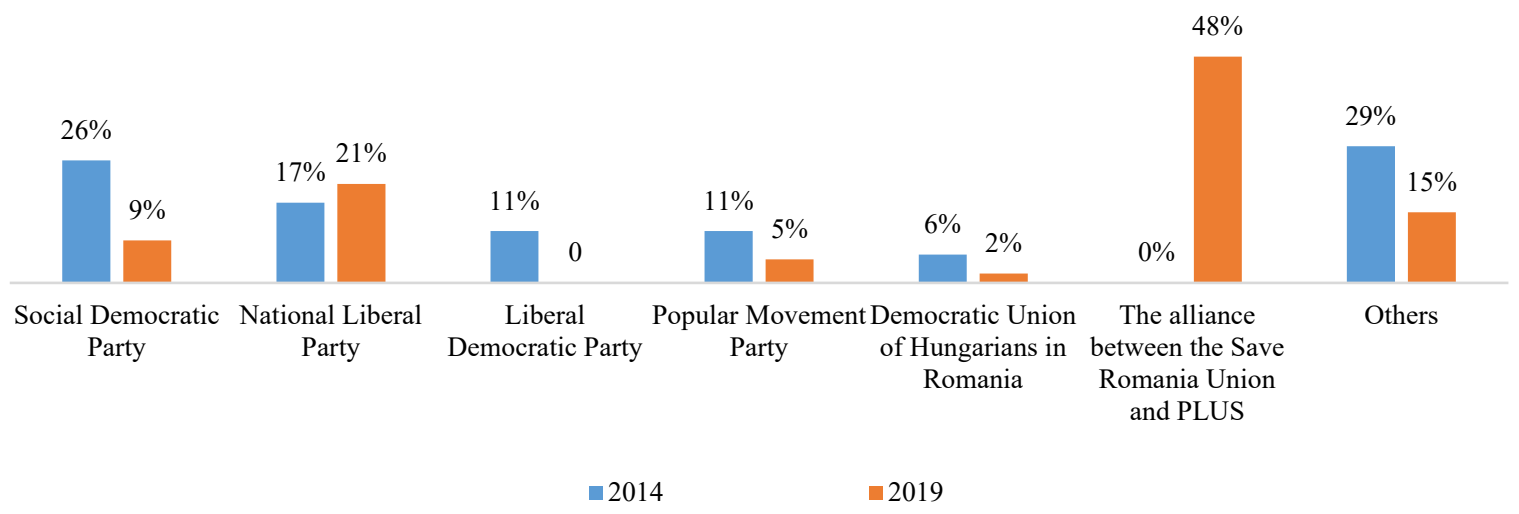

Figure 19. Higher education employees voting distribution the 2014 and 2019 European elections held in Romania

Source. Self-made

With regard to the voting rate amongst people with higher education, there is a significant difference between 2014 and 2019 elections. Among these voters, PNL managed to obtain more votes, adding $4 \%$. In $2014,26 \%$ of people with higher education employees voted for the PSD, while in 2019 , only $9 \%$ of them still voted for the PSD. The Save Romania UnionPLUS Alliance has had $48 \%$ of people with higher education vote for them in 2019. 


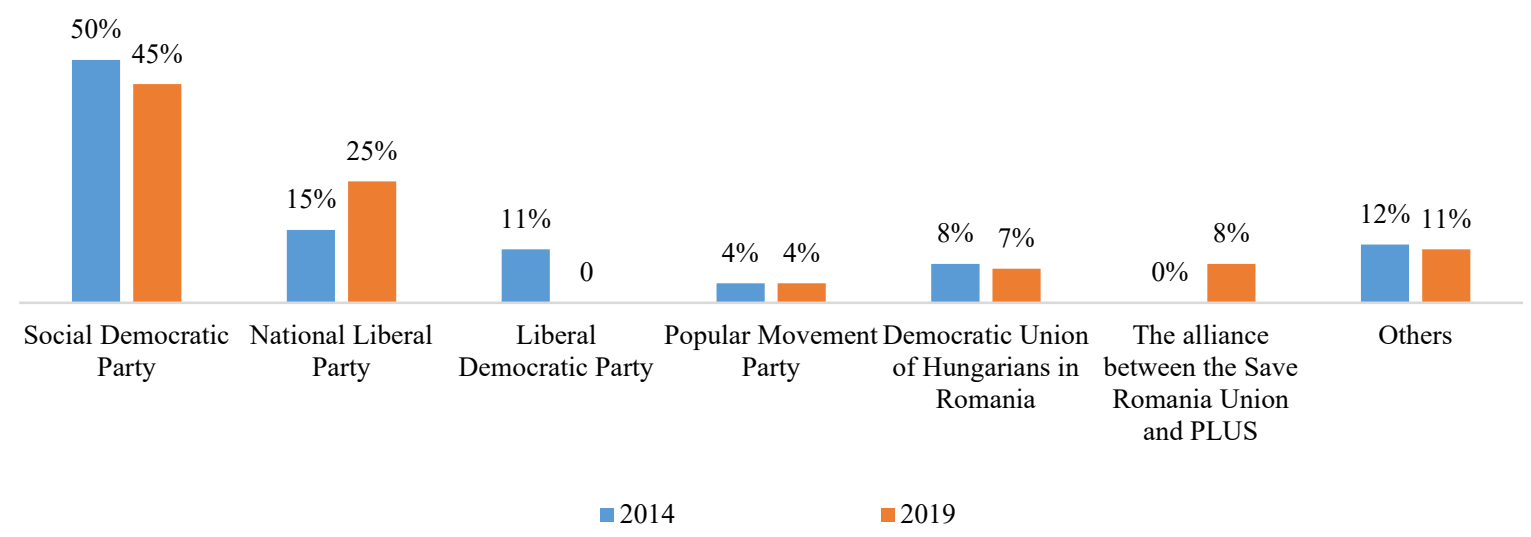

Figure 20. Less than high school voting distribution the 2014 and 2019 European elections held in Romania

Source. Self-made

Voters with no high school education had a linear behaviour. While in $2014,50 \%$ of them voted for the PSD, in 2019, 45\% cast their ballot for the same party, just a small difference between the two rounds of elections: 5\% of this group did not opt for PSD again. In 2014, $15 \%$ of people with no high school education voted for the PNL, while in 2019, this percentage climbed to $25 \%$. The $10 \%$ increase is explainable given that the Liberal Democratic Party, which had secured $11 \%$ in 2014, merged with the National Liberal Part that same year.

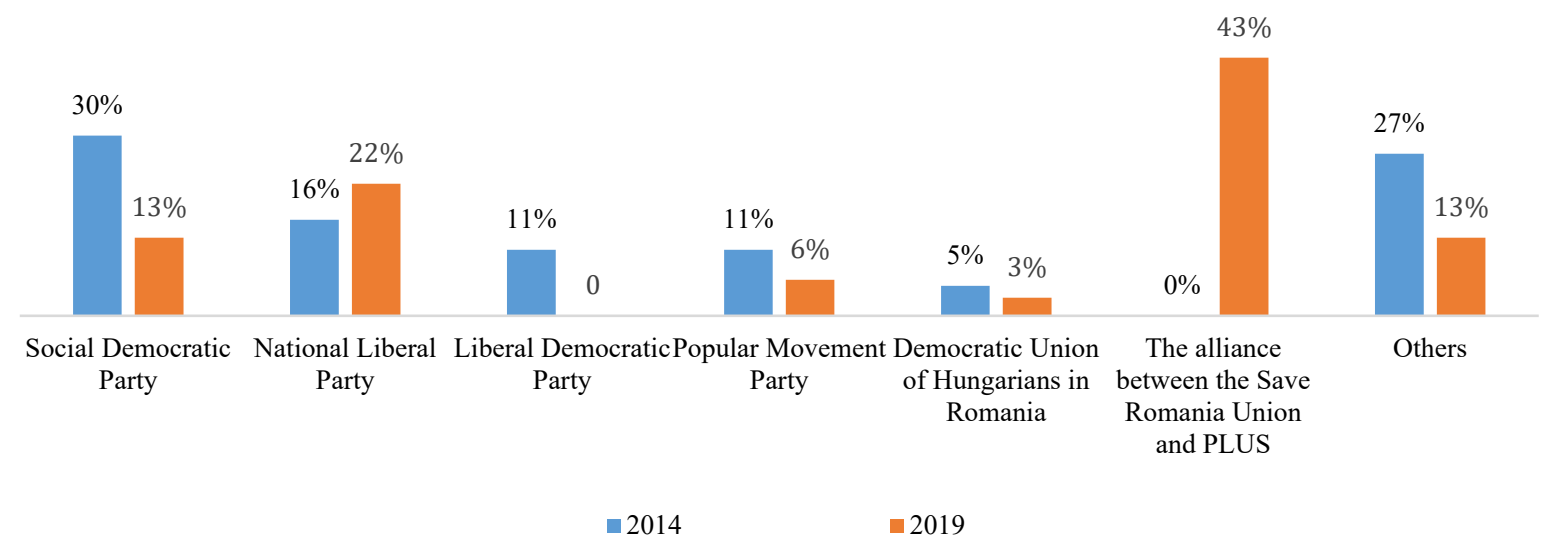

Figure 21. Comparison between the vote distribution of those with university degrees at the 2014 and 2019 European elections held in Romania

Source. Self-made

People with higher education had the same electoral behaviour as many other categories (students). They switched from the PSD in 2014 to the Save Romania Union-PLUS Alliance. 


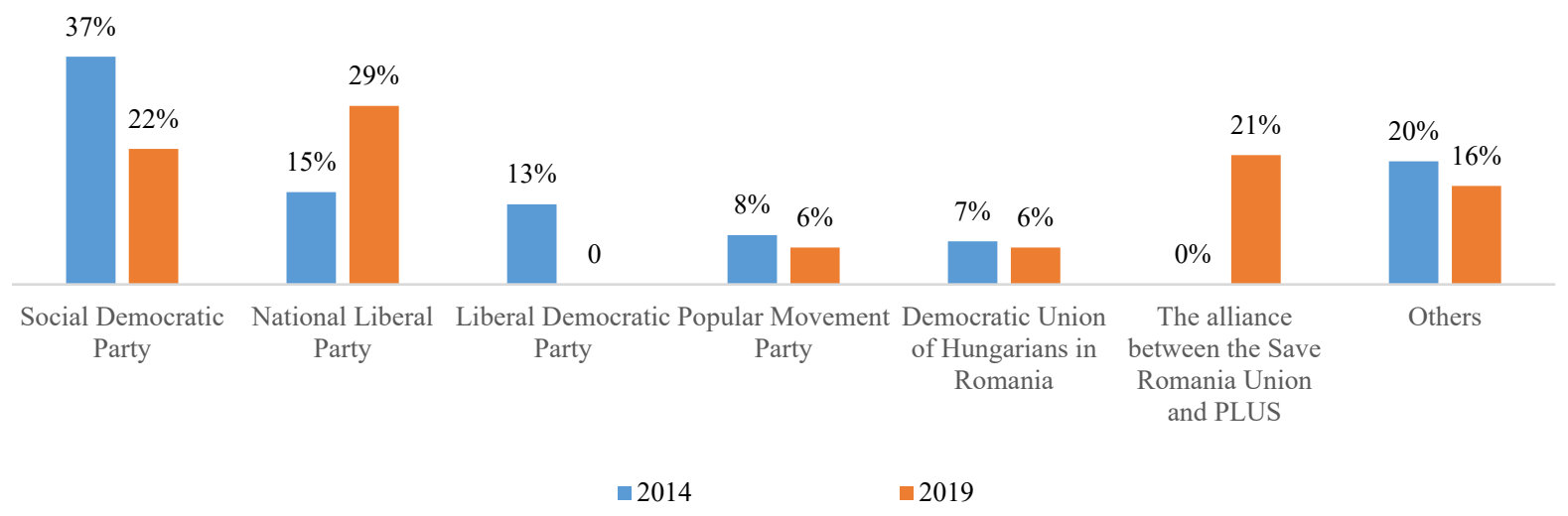

Figure 22. Comparison between the vote distribution of those with high school degrees at the 2014 and 2019 European elections held in Romania

Source. Self-made

University graduates, as well as people with high school education pursued the same path, as they left the PSD voters to join the USR-Plus voters.

\section{Conclusion}

Since Romania joined the EU, the country has had eleven prime ministers and a significant number of cabinet changes and prime ministers.

The profile of the Romanian electorate has changed for a range of motives. During the five years between the two rounds of elections, a new party anti-system emerged. The political turmoil determined the largest protests in the country's democratic history. Also, the turnout increased.

Political, economic, and social uproar has taken a heavy toll on the lives of millions of Romanians. Romania has one of the world's largest diaspora, in relation to the total domestic population of the country (Oecd-ilibrary.org, 2019).

In the past decade, the political behaviour of Romanians has included participation in protests, a new form of free speech, and direct democracy. Participation in political protests has played an increasingly important role mainly because Romanians reaped the obvious benefits of their involvement, spelt out as the withdrawal of the healthcare bill and of the decree regarding the controversial 2017 laws of the judiciary, as well as the resignations of prime ministers such as Emil Boc and Victor Ponta.

The turnout between 2007 and 2014 constantly stood at around 30\%. It peaked in 2019. Upon a closer look at the political behaviour in Romania a pattern can be noticed: each party has a stable electorate that constantly turns out to vote due to inertia. Furthermore, when the turnout increases is primarily a vote against" one party/politician. Romania has seen a great number of referenda in the past 12 years, but politicians have failed to deliver.

The polarization of society has played an important part in local political campaigns. In 2019, the high turnout was a mobilization against the Social Democratic Party after two years of riots against changes brought on by controversial laws of the judiciary.

The European elections have become a subject of interest for Romanians mainly because they perceive the EU as the guarantee of democracy and as a part of the solution to adjust economic and social disparities. Romanians' European identity is a social construct that has required time to develop. Globalization, as well as working and traveling without restrictions within the EU have contributed to the integration of European values into their own way of life. 
With regard to turnout, in 2019, the average Romanian voter in the European Parliamentary elections was a working male citizen with higher education. The most important difference between the 2014 elections and the 2019 elections is that in 2014, the average voter was a retired male citizen with higher education.

The average turnout of all elections that took place in Romania after 2007, after Romania's accession to the European Union, is $45.93 \%$. If we take into account referenda, Romanians have been urged to vote 21 times from 2007 until today, and the average turnout has been $44 \%$.

Except for 2019, when the European Parliamentary elections were held against the backdrop of increased social tensions in Romania, turnout at the European Parliamentary elections was below the average turnout at all elections.

The interest of Romanian society in the European parliamentary elections was low. Looking at the turnout at all elections for the European Parliament held in Romania, as well as the profiles of voters and of voters of different parties, one can argue that before the 2019 elections, the electorates of parties participated in the electoral process in a larger proportion. New voters swayed the outcome of the elections.

It took a harsh intervention of European leaders with respect to changes that the PSD Government intended to make on the laws of the judiciary, in the wake of the largest protests to take place in Romania after 1990, for people to realize the importance of the European Parliament elections. It was due to this general awareness that the USR, a new party with an aggressive agenda against mainstream parties, managed to become the third party.

The Romanian political class has only agreed with regard to one matter that happens to be quintessential - EU and NATO membership. This shared option lies at the core of our democracy.

\section{References}

Berelson, Bernard R., Lazarsefl, P. F., McPhee, W. N. (1986). Voting. A Study of Opinion Formation in a Presidential Campaign: Midway Reprint. Chicago: The University of Chicago Press.

Blondel, J. (1963). Voters, Parties and Leaders. The Social Fabric of British Politics. London: Penguin Books.

Butler, D., Stokes, D. E. (1974). Political Change in Britain. The Evolution of Electoral Choice. London: The Macmillan Press Ltd (Second edition).

Chamber of Deputies. (n.d.). Grupul parlamentar al Partidului Naţional Liberal. Retrieved April 4, 2020, from http://www.cdep.ro/pls/parlam/structura2015.gp?idl=1\&idg=2

Campbell, A., Converse, P. E., Miller, W. E., \& Stokes, D. E. (1980). The American Voter: Unabridged Edition, Chicago: The University of Chicago Press ( $3^{\text {rd }}$ ed.).

Central Election Bureau of Romania, (2019, June 3). Comunicat BEC privind lista partidelor politice, organizațiilor cetățenilor aparținând minorităților naționale, alianțelor politice, alianțelor electorale și candidaților independenți cărora li se pot repartiza mandate pentru

Parlamentul European 26 mai 2019. Retrieved September 2, 2020, from http://europarlamentare2019.bec.ro/wp-content/uploads/2019/06/BEC_E_COM_SGN_GS -P.pdf

Central Election Bureau of Romania, (2014, November 16). Proces-Verbal privind centralizarea voturilor la alegerile pentru Președintele României - 16 noiembrie 2014. 
Retrieved September 2, 2020， from http://bec2014.roaep.ro/rezultate-finale-16noiembrie/index.html

Eurostat, (2020, May). Income poverty statistics. Retrieved September 12, 2020, from https://ec.europa.eu/eurostat/statistics-explained/index.php?title=Income_poverty_ statistics\&oldid=440992\#At-risk-of-poverty_rate_and_threshold

Franklin, M. N. (2004). Voter Turnout and The Dynamics of Electoral Competition in Established Democracies Since 1945. New York: Cambridge University Press.

Government of Romania, (2017, January 18). Informație de presă privind proiectele de acte normative care ar putea fi incluse pe agenda şedinţei Guvernului României din 18.01.2017. Retrieved September 2, 2020, from https:/gov.ro/ro/guvernul/sedinteguvern/informatie-de-presa-privind-proiectele-de-acte-normative-care-ar-putea-fi-inclusepe-agenda-sedintei-guvernului-romaniei-din-18-01-2017

Lazarsfel, P. F., Berelson, B., Gaudet, H. (2004). Mecanismul votului. Cum se decid alegătorii într-o campanie prezidențială. București: Comunicare.ro.

Mayer, N., Schweisguth, E., (1989). Classe, position sociale et vote. In Daniel Gaxie (Ed.), Un bilan des études électorales en France (Deuxième edition, pp. 263-290). Paris: Presses de la Fondation Nationale des Sciences Politiques.

Michelat, G., Simon, M., (1971). Classe sociale objective, classe sociale subjective et comportement electoral. Revue française de sociologie. [Online]. vol. 12-4. pp. 483-527. Retrieved June 2, 2020, from https://www.persee.fr/doc/rfsoc_00352969_1971_num_12_4_2013

Mihai, C. (2019, December 10). Sondaj. Românii au mai multă încredere în instituțiile UE decât în cele naționale. Euractiv.ro. https://www.euractiv.ro/eu-elections-2019/romaniiau-mai-multa-incredere-in-ue-decat-in-institutiile-nationale.creste-si-numarulcontestarilor-16885

National Institute of Statistics in Romania, (2013, July). Recensământul populației și locuințelor - 2011. Retrieved June 2, 2020, from https://insse.ro/cms/files/publicatii/ pliante\%20statistice/04-recensamantul\%20populatiei.pdf

National Liberal Party, (n.d.). Scurt istoric al Partidului Liberal Național. Retrieved April 4, 2020, from https://pnl.ro/istoria-noastra/presedintii-pnl/

Nielsen, Julie Hassing, Franklin, Mark N. (editors), 2017. The Eurosceptic 2014 European Parliament Elections. Second Order or Second Rate? London: Palgrave Macmillan.

Norris, P., (2004). Electoral Engineering. Voting Rules and Political Behavior. New York: Cambridge University Press.

Organisation for Economic Cooperation and Development, (2019, July 16). Talent Abroad: A Review of Romanian Emigrants. Retrieved June 2, 2020, from https://www.oecdilibrary.org/sites/27927b96-en/index.html?itemId=/content/component/27927b96-en

Plutzer, E. (2002). Becoming a Habitual Voter: Inertia, Resources, and Growth in Young Adulthood. The American Political Science Review, 96(1), 41-56. Retrieved December 24, 2020, from http://www.jstor.org/stable/3117809

Presidential Administration of Romania. (n.d.). Președintele României Klaus Iohannis. Retrieved September 2, 2020, from https://www.presidency.ro/ro/presedinte/klausiohannis 
Presidential Administration of Romania, (2017, January 18). Declarațiile Președintelui României, domnul Klaus Iohannis, susținute la începutul ședinței de Guvern. Retrieved September 2, 2020, https://www.presidency.ro/ro/media/declaratii-de-presa/declaratiilepresedintelui-romaniei-domnul-klaus-iohannis-sustinute-la-inceputul-sedintei-de-guvern

Senate of Romania. (n.d.). Grupuri parlamentare. Retrieved April 4, 2020, from https://www.senat.ro/EnumGrupuri.aspx

The Social Democratic Party. (n.d.). Despre PSD. Retrieved June 30, 2020, from https://www.psd.ro/despre-psd/

Tufis, C. D., (2012). Learning Democracy and Market Economy in Post-Communist Romania. 